investigación económica, vol. LXX, 275, enero-marzo de 2011, pp. 15-38

\title{
Growth and convergence/divergence in productivity under balance-of-payments constraint
}

Esteban Pérez Caldentey

Anesa Ali*

\section{INTRODUCTION}

This paper presents a model of convergence/divergence in productivity for two economies of different size and development. More precisely the model postulates the existence of leader and follower economies. The leader has higher levels of productivity and is technologically more advanced. The follower economy is closely linked to the leader economy. Finally, the leader economy issues the international reserve currency.

The model presented builds on Kaldor's cumulative causation and the technological gap approaches to growth. Both operate within the logic of a balance-of-payments constraint framework. ${ }^{1}$

Received June 2010; accepted November 2010.

* Economic Commission for Latin America and the Caribbean (ECLAC), Santiago, Chile, <esteban. perez@cepal.org>, and Ministry of Foreign Affairs of Trinidad and Tobago, <anesa.ali.mfa@gmail. com>. The opinions here expressed are the authors' own and may not coincide with those of ECLAC or the Ministry of Foreign Affairs of Trinidad and Tobago. The authors would like to thank three anonymous referees for their valuable comments.

${ }^{1}$ Our view of Kaldor's cumulative causation and the balance-of-payments constraint framework follows the work of McCombie and Thirlwall (1994), McCombie et al. (2002), Thirlwall (1979) and McCombie and Thirlwall (1999). 
The cumulative causation approach views growth as being internally generated. Technological innovation generates, through the rise of embodied or disembodied productivity, growth in demand which feeds back into productivity growth. The growth linkage between productivity and demand is explained by terms-of-trade effects, increased income and expenditure, and changes in income distribution. The linkage from demand to productivity is explained by returns to scale, specialization and market size, embodied technical progress and learning by doing (Castellacci 2001). Seen from this perspective, growth is generated internally through innovation activity.

A limitation of this approach is that it does not contemplate that growth in demand could also be generated externally through technological spillovers between countries or that the international diffusion of technology can, in fact, occur through inter-country linkages. This is one of the main hypotheses of the technological gap approach which complements the cumulative causation approach described above.

The technological gap approach asserts that a country's growth rate depends on its level of technological development. It also states that countries whose technological level is below the world innovation frontier can increase their rate of growth through a process of "catching up" or imitation. Lastly, the absorptive capacity of such countries depends on their "ability to mobilize resources for transforming social, institutional and economic structures" (Fagerberg and Verspagen 2001:11). The technological gap approach recognizes that all countries are not alike, that development levels are an important determinant of growth and welfare and that not all countries benefit to a similar extent from trade and the transmission of trade linkages.

Cumulative causation and the technological gap approaches to growth operate in the model here presented within an external constraint encapsulated by the balance-of-payments constraint (BPC). This framework asserts that inter-country linkages and growth cannot be understood or analysed in real or "barter" terms. Trade and growth are intimately linked to the architecture and workings of the existing international financial order and the provision 
of liquidity as these are a fundamental constraint on economic growth and development. ${ }^{2}$

Economic relationships among countries are carried out in money terms and more precisely in terms of the international reserve currency or a given set of currencies. Countries can build up their economic infrastructure and develop by importing capital, raw materials, inputs and technology only if they are able to acquire the reserve currency or set of currencies (i.e., access to liquidity), which the great majority of countries cannot issue. As a result, countries' export potential must be commensurate with their import capacity.

Over the long run, consequently, countries that do not issue the international reserve currency, the follower economy in the model, must maintain equilibrium in the balance of payments or at least in the basic balance, since in the long run these countries (including the follower country) can only grow at rates compatible with their external position. It is in this sense that countries are said to be balance-of-payments-constrained. ${ }^{3}$

Within the logic of the model presented, for any given parameters, the rate of growth compatible with balance-of-payments equilibrium of the follower economy sets a boundary (a constraint), on the extent to which the workings of the cumulative causation mechanism and spillover 'technology' effects from the leader to the follower economy affect the productivity gap. In this sense, depending on the current circumstances

\footnotetext{
${ }^{2}$ This interpretation follows Davidson (1992:93-96; 2002:158-161).

${ }^{3}$ Countries are balance-of-payments-constrained in the sense that "their performance in overseas markets, and the response of the world financial markets to this performance, constrains the rate of growth of the economy to a rate which is below that which internal conditions would warrant" (McCombie and Thirlwall 1999:49). On the basis of the above definition Pérez Caldentey (2009a) defines the notion of balance-of-payments-constraint as follows "countries are said to be balanceof-payments constrained when their (current and expected) performance in overseas markets, and the response of the world financial markets to this (current and expected) performance, shapes and constrains their domestic policy space, including that of fiscal and monetary policy." We assume at this stage of the research that the BOP constraint falls on the follower economy. This is obviously a simplifying assumption that needs to be qualified in the future. We are aware that no country can maintain indefinite cumulative external deficits although some economies have more degrees of freedom than others. (See footnote 8).
} 
at hand the convergent (divergent) effects in productivity will be greater (smaller) the greater is the BPC rate of growth of the follower economy.

Thus contrary to mainstream approaches, financial and monetary factors captured by the BPC provide the framework for the operation and development of real forces, such as productivity. In other words, money and finance are fundamental determinants not only of growth but also of convergence.

The paper is divided in five sections. The first section presents the basics of the model. Section two and three provide the solutions to the model with and without capital flows and highlights the main implications. The fourth section introduces knowledge spillover effects. The fifth section presents the final thoughts.

\section{THE MODEL'S BUILDING BLOCKS}

The model begins by defining the technology gap $\left(G_{p}\right)$ between the leader and the follower economy $\left(P_{l}\right.$ and $P_{f}$, respectively) in logarithmic terms such that the rate of growth of the gap $(g)$ can be expressed as the difference between the rates of productivity change in the leader and follower country ( $p_{l}$ and $p_{f}$, respectively) (McCombie and Thirlwall 1994; Targetti and Foti 1997). That is,

$$
\begin{gathered}
G_{p}=\operatorname{Ln}\left(P_{l} / P_{f}\right) \\
g=p_{l}-p_{f}
\end{gathered}
$$

The rates of productivity growth in the leader and follower economies are equal to the sum of the rates of growth of autonomous (exogenous) and induced productivities. That is, they are modelled according to Verdoorn's Law. ${ }^{4}$ The interpretation of the autonomous and induced coefficients

\footnotetext{
${ }^{4}$ Verdoorn's Law is a "statistical relationship between the long-run rate of growth of labour productivity and the rate of growth of output, usually in the industrial sector" (McCombie et al. 2002:1). This relationship was formulated by Verdoorn (1949) and restated as a law by Kaldor (1966).
} 
adopted in this paper is that of Dixon and Thirlwall (1975) and McCombie and Thirlwall (1994). ${ }^{5}$

As stated by McCombie and Thirlwall (1994:464), autonomous productivity (denoted below by $p_{l a}$ and $p_{f a}$ for the leader and the follower respectively) depends on "the autonomous rate of disembodied technical progress, the autonomous rate of capital accumulation, and the degree to which technical progress is embodied in capital accumulation". For obvious reasons, the rate of autonomous productivity growth is higher in the leader economy than in the smaller country (i.e., $p_{l a}>p_{f a}$ ).

For its part, induced productivity is captured by the parameter $\lambda$ (denoted by $\lambda_{l}$ and $\lambda_{f}$ for the leader and the follower) also known as the Verdoorn coefficient. Again as stated by McCombie and Thirlwall (1994), it is a function of 'learning by doing', the degree to which capital accumulation is induced by economic growth (denoted by $y_{l}$ and $y_{f}$ for the leader and follower respectively) and the extent to which technical progress is embodied in capital accumulation". ${ }^{6}$ As well the induced productivity coefficient in the leader country is higher than that in the follower (i.e., $\lambda_{l}>\lambda_{f}$ ).

The productivity equations are thus specified as follows,

$$
\begin{aligned}
& p_{l}=p_{l a}+\lambda_{l} y_{l} \\
& p_{f}=p_{f a}+\lambda_{f} y_{f}
\end{aligned}
$$

Note that, as formulated, equations [3] and [4] capture the presence of increasing returns due to the greater specialization induced by economic growth. ${ }^{7}$ In turn, a greater degree of specialization entails a higher rate of

\footnotetext{
${ }^{5}$ Soro (2002:45-53) considers three interpretations of Verdoorn's Law. The first two were suggested by Verdoorn and are based on complementarity and perfect substitutability of the factors of production. The third, which is the one adopted in this paper, follows the Kaldorian interpretation. A key component of Kaldor's interpretation is the existence of increasing returns to scale. Following Young (1928), Kaldor subscribed to a macroeconomic rather than microeconomic concept of increasing returns. See Soro (2002) and Chandra and Sandilands (2005).

${ }^{6} \mathrm{~A}$ value of $\lambda>0.5$ indicates the presence of increasing returns.

${ }^{7}$ This means that increasing returns derive from specialization rather than scale. This is the position of Allyn Young and Nicholas Kaldor. See Young (1990).
} 
growth, which permits the expansion of the potential for specialization. Hence, the process described by equations [3] and [4] is cumulative.

As stated earlier, the follower economy is balance-of-paymentsconstrained. That is, its rate of growth has to conform in the long run to the rate of growth consistent with balance-of-payments equilibrium. Such is not the case with the leader economy because it issues the international reserve currency. ${ }^{8}$ Formally, the balance-of-payments constraint growth rate of the follower country can be expressed as a function of changes in the terms of trade (1), changes in real capital flows (2) and exogenous changes in the level of external income (3),

$$
\frac{(1+\theta \psi+\gamma)\left(p_{d f}-e-p^{*}\right)}{\xi}+\frac{\eta\left(f-p_{d f}\right)}{\xi}+\mu \frac{\pi y_{l}}{\xi}=y_{b p c f}
$$

The variables in equation [5] are denoted as follows: $y_{b p c f}$ is the rate of growth of the follower economy that is compatible with equilibrium in the balance of payments; $p_{d f}$ is the rate of change of domestic prices; $p^{*}$ is the rate of change of foreign prices; $y_{l}$ is the rate of growth of the leader (i.e., external income); $f$ is the rate of change in nominal financial flows; $e$ is the rate of change of the nominal exchange rate. The parameters are denoted as follows: $\gamma$ is the price elasticity of demand for imports $(\gamma<0)$; $\psi$ is the price elasticity of demand for exports $(\psi<0)$; $\xi$ is the income elasticity of demands for imports $(\xi>0) ; \pi$ is the income elasticity of demand for exports and $\mu$ and

\footnotetext{
${ }^{8}$ This is, at this stage of our work, a very simple assumption and the authors are cognizant that in a more complicated context the leader economy will not be able to maintain indefinite cumulative external deficits. Eventually as debt increases and becomes harder to service and finance creditors will expect, at some point, a currency depreciation or eventually some kind of default and will be reluctant to hold the leader's currency and its currency denominated assets. The upper bound on how much of the leader's debt creditors are willing to hold may depend on a host of factors including past history, sovereignty issues (increasing foreign debt implies that foreigners owe a greater share of the nation's, leader's economy, resources) and expectations. See, Pérez Caldentey (2009b) for a discussion of this issue along Keynes' arguments put forward in the General Theory (1936) and the Tract on Monetary Reform (1923).
} 
$\eta$ are the proportions of the total import bill financed with export earnings and capital flows, respectively. ${ }^{9}$

According to equation [5], the rate of growth of output of the follower economy is positively related to the rate of growth of external demand and weighted by the ratio of the export-to-import elasticities. The rate of expansion of real financial inflows also exerts a positive effect on output.

In a consistent manner with the approach adopted, we assume that the follower economy is a small economy and thus for all purposes takes prices as given so that the rate of growth of income of the follower country that is consistent with balance-of-payments constrained equilibrium depends on external demand (3) and on real capital flows (2). ${ }^{10}$ In this context real capital flows finance "growth in excess of the rate of growth consistent with equilibrium on the current account" (Thirlwall 1999).

$$
\frac{\eta(f-p)}{\xi}+\mu \frac{\pi y_{l}}{\xi}=y_{b p c d}
$$

BPC rate of growth of the follower country with capital flows.

\footnotetext{
${ }^{9}$ The rate of growth of an economy that is compatible with equilibrium in the balance of payments (equation [5]) is derived from a three equation model. The first is the rate of growth of imports expressed as a function of the real exchange rate and the rate of growth of the follower economy $\left(m_{f}=\psi\left(p^{*}+e-p_{d f}\right)+\xi y_{f}\right)$; the second is the rate of growth of exports expressed as a function of the real exchange rate and the rate of growth of the leader economy $\left(x_{f}=\gamma\left(p_{d f}-p^{*}-e\right)+\pi y_{l}\right)$; the third provides a dynamic equilibrium condition for the overall balance of payments equilibrium $\left(\mu\left(p_{d f}+\right.\right.$ $x)+\eta_{f}=p^{*}+m_{f}+e$ ). Equation [5] is then obtained by substituting the import and export equations into the equilibrium condition and solving for the rate of growth of the follower country.

10 The small country assumption is a convenient way to place the emphasis on income as opposed to substitution effects. The importance given to substitution effects in mainstream theory follows from the acceptance of the gross substitution axiom which views any good as a substitute of any other good. The gross substitution axiom presumes that money and finance are neutral, that is they play no role in the determination of real variables. Contrarily in the model here presented money and finance play a fundamental role in the determination of the international payments balance and real variables such as the determination of the rate of growth of output. See Davidson (1992:87-91) for a critical analysis of balance of payments' real adjustment mechanisms including relative price adjustments predominant in mainstream economics.
} 
In the limiting case where, the current account is in equilibrium, that is $\mu=1$ and $\eta=0$, the balance of payments constrained rate of growth $\left(y_{b p c f}\right)$ is expressed solely as a function of the rate of growth of world income and the income elasticities for exports and imports, that is financial flows have no influence on it. Formally,

$$
\frac{\pi y_{l}}{\xi}=y_{b p c f}
$$

BPC of growth of the follower country with no capital flows.

Equation [7] is known as Thirwall's Law. It postulates that the longterm growth rate of the follower economy $\left(y_{f}\right)$ is determined by the long-term growth rate of the leader economy $\left(y_{l}\right)$ multiplied by the income-elasticity ratio between the follower country's exports to the rest of the world $(\pi)$ and the income-elasticity of its demand for imports $(\xi)$.

The BPC literature presents three different hypotheses regarding the determinants of the income-elasticities of imports and exports. The first follows from Prebisch and Singer and relates the size of the elasticity parameters to the manufacturing and technological content of the products exported and imported. According to this reasoning, the income-elasticity of exports increases as external sales move up the value-added chain from commodities to semiprocessed labour - and resource-intensive goods, then to manufactures with low, medium and high skill and technology content. In the case of developing economies, the income-elasticity of demand for their exports in the rest of the world is low and the income-elasticity of their demand for imports is high. Less developed countries exporting commodities subject to Engel's Law are usually in this category (Davidson 1992). The main policy implication, following the logic of Thirlwall's Law, is that unless countries undergo a process of structural change that alters the elasticity parameters, the cleavage between developed and developing economies will widen over time and less developed countries are condemned to poverty.

The second hypothesis states that while the income-elasticity of a country's demand for imports tends to remain more or less constant, the 
income-elasticity of its exports to the rest of the world varies over time with the level of development (Bairam 1997). More specifically, the incomeelasticity of demand for a country's exports in the rest of the world is inversely related to its level of development and tends to decline as this level rises. As a result, increases in external demand or expansionary phases in the global cycle (or that of the country's main trading partners) have a positive effect on developing countries' external position.

The third hypothesis maintains that changes in the said income-elasticities are brought about by shifts in commercial policy or measures designed to transfer liquidity between countries, or both. Changes in commercial policy involve changes in trade barriers (tariffs and quotas). Measures to recycle liquidity comprise increases in surplus nations' imports and unilateral transfers from surplus to deficit nations (Davidson 1992:153).

The available empirical work shows that the income-elasticity of imports tends to rise with trade liberalization and that the income-elasticity of exports depends on what the market and consumers and producers are demanding at a given time. Thus, while the income-elasticity of imports depends on institutional factors which include changes in commercial policy, as per the third hypothesis, there seems to be no clear core factor determining the income-elasticity of exports.

\section{ThE SOLUTION TO THE MODEL WITHOUT CAPITAL FLOWS}

Starting with the no capital flows case, substitution of equation [7] above into equation [4] and of equations [4] and [3] into equation [2] yields the following expression for the rate of change in the productivity gap,

$$
g=\left(p_{l a}-p_{f a}\right)+\lambda_{l} y_{l}-\lambda_{f}\left[\frac{\pi y_{l}}{\xi}\right] \Leftrightarrow\left(p_{l a}-p_{f a}\right)+y_{l}\left(\lambda_{l}-\lambda_{f} \frac{\pi}{\xi}\right)
$$

Equation [8] shows that the rate of change in the productivity gap over time will depend on three factors: (i) the differences in autonomous productivities 
$\left(p_{l a}-p_{f a}\right)$; (ii) the induced productivity of the leader economy $\left(\lambda_{l} y_{l}\right)$; (iii) Thirlwall's Law weighted by the induced productivity of the follower economy $\left.\lambda_{f}\left(\pi y_{l} / \xi\right)\right)$. By contrast to other approaches found in the literature, relative prices do not play a role in the workings of Verdoorn's law. ${ }^{11}$

According to equation [8] when the leader economy's growth rate tends to zero $\left(y_{l}->0\right)$, the rate of growth in the productivity gap $(g)$ is equal to the difference between the autonomous productivities $\left(p_{l a}-p_{f a}\right)$. The difference is by assumption of the model positive and thus under this case both economies diverge. This is a case of absolute divergence.

When the leader economy exhibits positive rates of growth (and assuming that the difference in autonomous productivities between the leader and follower economies is equal to zero $\left(p_{l a}-p_{f a}=0\right)$ there are simultaneous divergence and convergence effects. Both of these are examined in turn under the assumption of constant induced productivity and income elasticity parameters.

On the one hand, a positive rate of growth of the leader economy generates a divergence effect that works through the induced productivity of the leader economy $\left(y_{l} \lambda_{l}\right)$. An increase in $y_{l}$ translates into an increase in $g$ (productivity gap) of magnitude $\lambda_{l}$. And other things remaining the same, the greater is the rate of growth of the leader economy the greater is the productivity gap (i.e., the greater is the divergence). We term this effect, which is a growth without convergence effect, the 'Kaldor-effect.'

\footnotetext{
${ }^{11}$ As indicated in footnote 10, the approach adopted in this paper follows the post-Keynesian tradition in emphasizing income over substitution effects (Davidson 1992:22). According to this view, relative prices do not play a role in the determination of the long-run Gross Domestic Product (GDP) growth rate or the productivity gap. See Dixon and Thirlwall (1975) and León-Ledesma (2002) for a different approach in which the effect of Verdoorn's Law works through relative prices. In León-Ledesma (2002), exports are a function of relative prices which are then made dependent on the difference between the wage rate and productivity. Thus productivity determines (for a given wage rate) prices and through relative prices, exports and hence the rate of output growth. This transmission channel is not included in the model for the conceptual reasons provided in footnote 10 and moreover because the various empirical estimates of the demand for exports which show that the relative price variable is not statistically significant.
} 
At the same time, the rate of growth of the leader economy produces a convergent effect. The convergence effect stems from the workings of Thirlwall's Law. For a given ratio of the income elasticities an increase in the rate of growth of the leader economy has a pull effect on the follower economy in the same direction. The strength of the pull effect is dependent on the ratio of income elasticities $(\pi / \xi)$ weighted by the induced productivity coefficient of the follower economy $\left(\lambda_{f}\right)$. We term this growth with convergence effect, the 'Thirwall-effect'. We term it a convergence effect simply because for a given set of income elasticity parameters and the induced productivity of the follower $\left(\lambda_{f}\right)$ an increase in the rate of growth of the leader economy translates into a negative rate of growth of the productivity gap. ${ }^{12}$

While both effects coexist, whether ultimately the productivity of the follower economy converges or diverges from that of the leader will thus depend on the relative strengths of the Kaldor and Thirlwall effects. This in turn depends on the size of the different parameters involved, that is on the size of the induced productivities $\left(\lambda_{l}\right.$ and $\left.\lambda_{f}\right)$ and on that of the income elasticities $(\pi$ and $\xi$ ).

More precisely, the rate of change in the gap will increase, decrease or be equal to zero depending on whether the ratio of the income (import and export) elasticities of the follower country weighted by its induced productivity coefficient is greater than, less than or equal to the induced productivity coefficient of the leader country. Alternatively, this can be stated in the following way: the rate of change in the gap will increase, decrease or be equal to zero depending on whether the ratio of the induced productivity coefficients between the leader and follower economies is greater than, less than or equal to the ratio between the income-elasticity of the follower country's exports to the rest of the world and the incomeelasticity of its imports. Formally,

\footnotetext{
${ }^{12}$ We are not referring here to the income gap between leader and follower economies but to the gap in productivity between the leader and follower economy for a given set of coefficients. Obviously in a further stage of the research, once we allow for changes in the parameters the analysis is open to more complex possibilities and outcomes.
} 


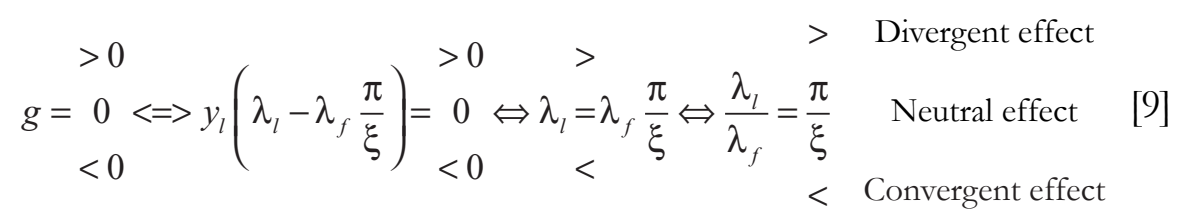

Since the model by assumption postulates that $\lambda_{l}>\lambda_{f}$ convergence requires not only that $\pi>\xi$ but that in addition their difference must be wide enough to outweigh the differences between $\lambda_{l}$ and $\lambda_{f}$.

\section{THE SOLUTION TO THE MODEL INCLUDING CAPITAL FLOWS}

Adding capital flows to the model does not modify substantially the above conclusions. In this case, the rate of change of the productivity gap will depend not only on the determinants identified previously but also on real capital flows adjusted for the induced productivity of the follower country. Formally,

$$
\begin{aligned}
g= & \left(p_{l a}-p_{f a}\right)+\lambda_{l} y_{l}-\lambda_{f}\left[\frac{\eta(f-p)}{\xi}+\mu \frac{\pi y_{l}}{\xi}\right]<= \\
& \left(p_{l a}-p_{f a}\right)+y_{l}\left[\lambda_{l}-\lambda_{f} \mu \frac{\pi}{\xi}\right]-\lambda_{f}\left[\frac{\eta(f-p)}{\xi}\right]
\end{aligned}
$$

When considered in isolation, capital flows will reduce the productivity gap, that is, they have a convergent effect. They have a negative sign and as a result, other things remaining the same, an increase in the rate of growth of capital flows will result in a negative rate of growth of the productivity gap (i.e., the productivity gap will narrow). The extent to which capital flows are able, under the caeteris paribus assumption, of narrowing the productivity gap will depend on the productivity of the follower economy relative to its import elasticity $\left(\lambda_{l} / \xi\right)$. The more productive is the follower economy 
and the less it relies on imports (or the greater its import productivity), the more potent will be the capital flow effect. ${ }^{13}$

When viewed in interaction with the rate of growth of the leader economy, the incorporation of capital flows is justified only under the assumption that the import elasticity is greater than the export elasticity $(\xi>\pi)$. In this case the follower country will have a recurrent deficit in its current account and will require capital flows to balance its balance of payments. If as assumed in the model, $\lambda_{l}>\lambda_{f}$ and $\xi>\pi$, then it follows that $\lambda_{l} / \lambda_{f}>\pi / \xi$ (i.e., the Kaldor effect is greater than the Thirlwall effect) and as result, for a positive rate of growth of the leader economy $\left(y_{l}\right)$, capital flows will have a convergent role only if the rate of growth of capital flows weighted by the induced productivity of the follower economy (i.e., the capacity of the follower economy to use capital flows productively) is able to compensate and outweigh for the predominance of the Kaldor effect over the Thirlwall effect. Formally,

$$
g<0 \Leftrightarrow\left|y_{l}\left(\lambda_{l}-\lambda_{f} \mu \frac{\pi}{\xi}\right)\right|<\left|\lambda_{f}\left[\frac{\eta(f-p)}{\xi}\right]\right|
$$

\section{THE MODEL WITH SPILLOVER KNOWLEDGE EFFECTS}

Up to this point the model was developed on the basis that the only interaction between the leader and the follower economies occurred through the rate of growth of the leader economy. However, when countries trade and become interdependent, there are other types of spillover effects between both. A significant spillover effect is the diffusion of knowledge which is actually an important vehicle for the transmission of economic development. ${ }^{14}$ In this section the model incorporates the developmental dimension to the growth impact on the productivity gap.

\footnotetext{
${ }^{13}$ We owe the term 'import productivity' to Vanus James (University of the West Indies, MONA Campus, Jamaica) who introduced it to us in 2005 during a conference organized by the Caribbean Center for Monetary Studies.

${ }^{14}$ See Helpman (2004:60-69) and Rogers (2004).
} 
Furthermore, in addition to the above limitation, the explicit causality in the model ran from autonomous and induced productivities (Kaldor's effect), capital flows and Thirwall's Law (Thirlwall effect) to the productivity gap without due consideration for the possible endogeneity from the productivity gap $(g)$ to induced productivities. The introduction of the developmental aspect of the interaction between both economies in the form of knowledge spillovers corrects for this shortcoming by postulating that the learning capacity of the follower economy is dependent on the size of the productivity gap.

Within the setting of our model, both aspects are incorporated by postulating that the spillover effects of knowledge are transmitted from the bigger, more developed economy (the leader) to the smaller, less developed one (the follower) via the absorptive or learning capacity of the latter. The induced productivity of the follower economy is made a function of the absorptive capacity. The greater is the absorptive capacity of the follower, the more powerful the knowledge spillover effect. ${ }^{15}$ However, absorptive capacity is limited by the extent of the productivity gap between the two economies and thus the induced productivity of the follower economy is endogenous to the productivity gap. ${ }^{16}$

For the sake of analytical simplicity and without sacrificing any of the analytical contents, the bulk of the analysis that follows takes into consideration the case with no capital flows. That is, it assumes that the follower economy maintains equilibrium in its current account balance.

Following Targetti and Foti (1997), induced productivity can be modeled as a non-linear function of the gap. Formally,

\footnotetext{
15 According to Abramovitz (1979, 1986 and 1995), countries can realize their catch-up potential if they exhibit "social capability" and "technological congruence" and possess natural resource endowments. The term "social capability" includes a wide variety of factors, including social attitudes and political institutions, educational attainment, organizational and commercial skills and adequate levels of infrastructure. The term "technological congruence" refers to the fact that technology in the leader economy may not always be appropriate for the follower economy (Verspagen and Los 2002; Criscuolo and Narula 2002).

${ }^{16}$ See Nelson and Phelps (1966), Abramovitz (1986), Targetti and Foti (1997) and Rogers (2004).
} 


$$
\lambda f=a\left(\frac{1}{G_{0}}\right)\left(e^{\frac{-G}{\theta}}\right)=a \varphi\left(e^{\frac{-G}{\theta}}\right)
$$

Where: $a$ is the factor of proportionality; $\varphi$ is $\left(1 / G_{0}\right)=$ inverse of the initial productivity gap and $0<\varphi<1 ; \theta$ is the parameter reflecting the adaptability or learning capacity of the follower economy.

According to equation [12], induced productivity in the follower country is proportional to the inverse of the initial productivity gap. That is, the greater (smaller) the initial productivity gap, the lower (higher) $\varphi$ will be and, other things being equal, the weaker (stronger) the spillover effect.

Equation [12] is also a function of the extent to which the follower economy is able to acquire and incorporate knowledge from the leader economy (i.e., of the absorptive or learning capacity of the follower economy). ${ }^{17}$ This is captured by $e^{-G / \theta}$. The basic mathematical properties of equation [12] are listed below and figure 1 plots the function.

$$
\begin{gathered}
\operatorname{Lim}_{\theta \rightarrow 0} \lambda_{f}=0 \quad \text { and } \quad \operatorname{Lim}_{\theta \rightarrow \infty} \lambda_{f}=a\left(1 / G_{0}\right) \\
\lambda_{f^{\prime}}(\theta)=a\left(1 / G_{0}\right)\left(G / \theta^{2}\right)\left(e^{-G / \theta}\right)>0 \\
\operatorname{Lim}_{\theta \rightarrow 0} \lambda_{f^{\prime}}=\infty \quad \text { and } \quad \operatorname{Lim}_{\theta \rightarrow \infty} \lambda_{f^{\prime}}=0
\end{gathered}
$$

Induced productivity is an increasing function of the parameter $\theta$. However, as $\theta$ increases, induced productivity tends to the limit $\left(1 / G_{0}\right)$. That is, the extent to which the follower country is able to use its learning capacity to catch up with the leader economy is bounded by the initial productivity gap $\left(G_{0}\right)$. This is in fact the boundary of the country's learning capacity. The greater the initial productivity gap, the lower the "learning capacity boundary", as

\footnotetext{
${ }^{17}$ Absorptive capacity is defined by Dahlman and Nelson (1995) as "the ability to learn and implement the technologies and associated practices of already developed countries". It is a narrower concept than "social capability". According to Rogers (2004:579), absorptive or learning capacity depends on "accessibility to overseas technology, learning ability, and the incentives or barriers to implementing new technologies".
} 
Figure 1

Induced productivity of the follower country

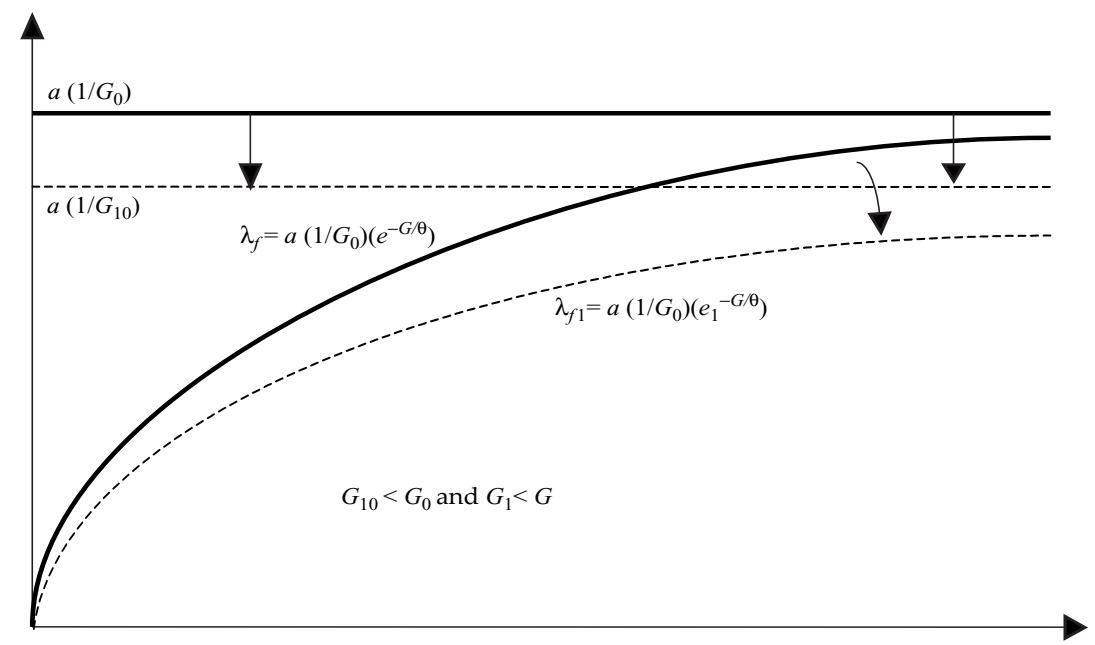

Source: prepared by the authors.

shown in figure 1 by the difference between the continuous straight line (corresponding to $G_{0}$ ) and the dashed straight line (corresponding to $G_{10}$ and $G_{10}>G_{0}$ ). Similarly, any increase in the actual gap, whatever its initial size, reduces the follower's induced productivity. This too is shown in figure 1, by the difference between the straight and dashed lines of induced productivities $\left(\lambda_{f}\right.$ and $\lambda_{f 1}$, respectively), which correspond to different sizes of gap ( $G$ and $G_{1}$, respectively, where $G_{1}>G$ ).

Substituting equation [13] into equation [12] yields the following expression for the rate of change in the gap:

$$
\begin{aligned}
g= & \left(p_{l a}-p_{f a}\right)+\lambda_{l} y_{l}-\left[\left(a \varphi e^{\frac{-G}{\theta}}\right) \frac{\pi y_{l}}{\xi}\right] \Leftrightarrow> \\
& \left(p_{l a}-p_{f a}\right)+y_{l}\left(\lambda_{l}-\left(a \varphi e^{\frac{-G}{\theta}}\left(\frac{\pi}{\xi}\right)\right)\right)
\end{aligned}
$$


As stated previously and in consonance with the logic of the model, equation [14] shows that when the rate of growth of the leader country tends to zero (i.e., $y_{l} \rightarrow 0$ ) the difference in autonomous productivities between the leader and follower countries has an absolute divergence effect (i.e., $g=p_{a l}-p_{a f}>0$ ). As well, positive rates of growth of the leader economy $\left(y_{l}>0\right)$ have at the same time convergent and divergent effects on the productivity gap.

The divergent effect is given by the 'Kaldor effect' $\left(y_{l} \lambda_{l}\right)$. It is the same as that identified in the previous section. The convergent effect is captured, as in the previous section, by Thirwall's Law $\left(y_{l}(\pi / \xi)\right)$. In addition, once spillovers are introduced, this convergent effect is weighted by the initial productivity gap $(G)$ and the extent to which the follower country can benefit from the spillover effects, which basically depends on its adaptability or learning capacity $(\theta)$. And again, a positive rate of growth of the leader economy $\left(y_{l}>0\right)$ will result in convergence or divergence in productivity between both economies depending on whether the Thirlwall effect can (or cannot) outweigh the Kaldor effect. Formally,

$$
\begin{aligned}
g>0= & \lambda_{l}-\left(a \varphi e^{\frac{-G}{\theta}}\left(\frac{\pi}{\xi}\right)\right)>0 \Leftrightarrow \\
& \lambda_{l}>a \varphi e^{\frac{-G}{\theta}}\left(\frac{\pi}{\xi}\right) \Leftrightarrow \frac{\lambda_{l}}{a \varphi e^{\frac{-G}{\theta}}}>\left(\frac{\pi}{\xi}\right) \quad \text { Divergent gap path } \\
g=0 \Rightarrow & \lambda_{l}-\left(a \varphi e^{\frac{-G}{\theta}}\left(\frac{\pi}{\xi}\right)\right)=0 \Leftrightarrow \\
& \lambda_{l}=a \varphi e^{\frac{-G}{\theta}}\left(\frac{\pi}{\xi}\right) \Leftrightarrow \frac{\lambda_{l}}{a \varphi e^{\frac{-G}{\theta}}}=\left(\frac{\pi}{\xi}\right) \quad \text { Neutral gap path } \\
g<0= & \lambda_{l}-\left(a \varphi e^{\frac{-G}{\theta}}\left(\frac{\pi}{\xi}\right)\right)<0 \Leftrightarrow \\
& \lambda_{l}<a \varphi e^{\frac{-G}{\theta}}\left(\frac{\pi}{\xi}\right) \Leftrightarrow \frac{\lambda_{l}}{a \varphi e^{\frac{-G}{\theta}}}<\left(\frac{\pi}{\xi}\right) \quad \text { Convergent gap path }
\end{aligned}
$$




\section{A SUMMING-UP OF THE MODEL AND ITS POLICY IMPLICATIONS}

The paper develops a leader-follower model to determine the possibility of convergence or divergence between a developed and developing economy. The leader (developed) economy is typified as the larger and more technologically advanced of the two and also as the economy which provides the international reserve currency. The developed economy is the motor of growth of this two-economy world. The model builds on the notion of cumulative causation and the technological gap approach and the workings of both are bounded by the balance-of-payments constraint which applies to the developing (follower) economy.

The model shows that when the leader economy expands its rate of growth, the follower economy also grows. That is, it postulates a co-movement in growth between developed and developing economies (provided their linkages are strong as postulated in the model). For obvious reasons, this makes the follower economy also susceptible to downturns when the growth of the leader economy contracts.

However, the model shows that co-movement in growth does not mean narrowing the divergence in the productivity gap when the leader economy grows. The model in fact distinguished between divergence induced growth and convergence induced growth. Divergence induced growth works through cumulative causation (the Kaldor effect). Convergence induced growth works via Thirlwall's Law (Thirlwall effect).

Whether ultimately, the growth of the leader economy will result in convergent or divergent growth will depend on the relative strength of both effects. The predominance of the Kaldor over the Thirlwall effect leads to divergence. Contrarily the predominance of the Thirlwall over the Kaldor effects leads to convergence. Formally within the logic of the model this reduces to the proposition that convergence/divergence depends on whether the income export-to-import elasticities of the follower is greater/smaller than the difference in the induced productivity coefficients (see table 1 below for a summary of the basic here sued and its variations).

Thus while growth simply happens as long as the leader economy grows, unless the follower economy is already converging to the leader, achieving 
convergence requires specific policies to change the elasticity parameters and/or the induced productivity coefficients. That is policies are needed to ensure that the Thirlwall effect predominates over the Kaldor effect.

Needless to say, these policies must be consistent and the lack of consistency may defeat the purpose of convergence. As an example depending on the context, circumstance and sequencing, a policy geared to improve the valued added content of exports (which could under certain conditions increase the export elasticity of income, $\pi$ ) can clash with a trade liberalization policy which can result in an increase of the income elasticity of imports $(\xi)$.

TABLE 1

Summary of the types of models and conditions for convergence

Types of models Model formalization

Kaldor effect

Basic model (M1)

$$
g=\left(p_{l a}-p_{f a}\right)+y_{l}\left(\lambda_{l}-\lambda_{f} \frac{\pi}{\xi}\right)
$$

[8] $y_{l} \lambda_{l}$

Model with capital flows (M2)

$$
g=\left(p_{l a}-p_{f a}\right)+y_{l}\left[\lambda_{l}-\lambda_{f} \mu \frac{\pi}{\xi}\right]-\lambda_{f}\left[\frac{\eta(f-p)}{\xi}\right][10] \quad y_{l} \lambda_{l}
$$

Model with diffusion of knowledge (M2)

$$
g=\left(p_{l a}-p_{f a}\right)+y_{l}\left(\lambda_{l}-\left(a \varphi e^{\frac{-G}{\theta}}\left(\frac{\pi}{\xi}\right)\right)\right) \quad[14] \quad y_{l} \lambda_{l}
$$

Types of models Thirwall effect Conditions for convergence

Basic model (M1)

$$
-y_{l} \lambda_{f}\left(\frac{\pi}{\xi}\right) \quad \frac{\lambda_{l}}{\lambda_{f}}<\frac{\pi}{\xi}
$$

Model with capital flows (M2)

$$
\begin{array}{r}
-y_{l}\left[\lambda_{f} \mu \frac{\pi}{\xi}\right]-\lambda_{f}\left[\frac{\eta(f-}{\xi}\right. \\
-y_{l}\left(a \varphi e^{\frac{-G}{\theta}}\left(\frac{\pi}{\xi}\right)\right)
\end{array}
$$$$
\left|y_{l}\left(\lambda_{l}-\lambda_{f} \mu \frac{\pi}{\xi}\right)\right|<\left|\lambda_{f}\left[\frac{\eta(f-p)}{\xi}\right]\right|
$$

Model with diffusion of knowledge (M2)

$$
-y_{l}\left(a \varphi e^{\frac{-G}{\theta}}\left(\frac{\pi}{\xi}\right)\right) \quad \frac{\lambda_{l}}{a \varphi e^{\frac{-G}{\theta}}}<\frac{\pi}{\xi}
$$


Nevertheless the design and implementation of policies to achieve the right balance between the ratio of income elasticities $(\pi / \xi)$ and that of induced productivity coefficients $\left(\lambda_{l} / \lambda_{f}\right)$ such that $\pi / \xi>\lambda_{l} / \lambda_{f}$ can be a difficult task. It requires enormous and conscious efforts of coordination and wide and effective policy leverage to change the above parameters.

This point is illustrated through a calibration exercise for the case of Central American countries and Mexico, a set of follower countries, whose economic fortunes are closely linked to those of a leader country, i.e., the United States. Table 2 below shows the import-export elasticity parameters for Central American countries and Mexico and the induced productivity coefficients for these countries and the United States.

The import-export elasticity parameters correspond to different estimates found in the literature for different time periods and also in the case of the export elasticity parameters own estimations are included. The value of the induced productivity coefficient for the United States (the leader country) was set at 0.6 which is at the highest end of the range of estimates found for advanced countries. ${ }^{18}$ In the case of Central American countries and Mexico, the value for the induced productivity coefficient was set at 0.2 which is below the lowest value found for advanced countries (see footnote 18).

The exercise in question seeks to determine the value of the export elasticity parameter that given the maximum and minimum import elasticity parameters found in the BPC literature and the induced productivity coefficients, would ensure, according to the basic model presented in the paper, that growth in the leader country generates convergence in productivity for the follower country.

As can be readily seen, in the best and most optimist of the cases which is that derived from using the minimum value for the import elasticity of demand and the highest value for the export elasticity of exports, the export elasticity parameter would have to increase by at least 1.45 and 1.58 points

${ }^{18}$ The estimates of the Verdoorn coefficient range from 0.3 to 0.6 for advanced countries. See McCombie et. al. (2002:106). 
to ensure convergence in productivity in Mexico and Costa Rica; more than double in the case of El Salvador; and more than triple in the case of Guatemala (see table 2 below).

TABLE 2

Calibration exercise using the basic model to obtain the export elasticity of income required for convergence in producivity

$\xi$

\begin{tabular}{|c|c|c|c|c|c|}
\hline Countries & $\begin{array}{c}\text { Pacheco López } \\
\text { 1977-2002 }\end{array}$ & $\begin{array}{c}\text { Senhadji } \\
\text { 1960-1993 }\end{array}$ & $\begin{array}{c}\text { Perraton } \\
1973-1995\end{array}$ & \multicolumn{2}{|c|}{$\begin{array}{c}\text { Pérez Caldentey and } \\
\text { Moreno-Brid } \\
\text { 1950-1997 }\end{array}$} \\
\hline Costa Rica & 2.27 & 1.21 & 1.76 & \multicolumn{2}{|c|}{1.69} \\
\hline El Salvador & 2.47 & 1.47 & $\ldots$ & \multicolumn{2}{|c|}{0.95} \\
\hline Guatemala & 3.78 & $\ldots$ & $\ldots$ & \multicolumn{2}{|c|}{1.35} \\
\hline Honduras & 1.41 & 0.74 & 0.56 & \multicolumn{2}{|c|}{0.92} \\
\hline Nicaragua & 0.97 & 0.57 & $\ldots$ & \multicolumn{2}{|c|}{1.92} \\
\hline Mexico & 3.17 & 1.31 & $\ldots$ & \multicolumn{2}{|c|}{$\ldots$} \\
\hline United States & - & - & - & \multicolumn{2}{|c|}{ - } \\
\hline & \multicolumn{2}{|l|}{$\pi$} & & \multicolumn{2}{|c|}{$\pi^{r}$} \\
\hline Countries & $\begin{array}{c}\text { Moreno-Brid and } \\
\text { Pérez Caldentey } \\
\text { 1950-1999 }\end{array}$ & $\begin{array}{c}\text { Own } \\
\text { estimates } \\
\text { 1960-2005 }\end{array}$ & $\lambda$ & $\begin{array}{c}\text { With } \\
\text { maximum } \\
\xi\end{array}$ & $\begin{array}{c}\text { With } \\
\text { minimum } \\
\xi\end{array}$ \\
\hline Costa Rica & 2.64 & 2.31 & 0.2 & $>6.81$ & $>3.63$ \\
\hline El Salvador & 2.24 & 1.42 & 0.2 & $>7.41$ & $>2.85$ \\
\hline Guatemala & 1.07 & 1.38 & 0.2 & $>11.34$ & $>4.05$ \\
\hline Honduras & $\ldots$ & $\ldots$ & 0.2 & $\ldots$ & $\ldots$ \\
\hline Nicaragua & $\ldots$ & $\ldots$ & 0.2 & $\ldots$ & $\ldots$ \\
\hline Mexico & $\ldots$ & 2.70 & 0.2 & $>9.51$ & $>3.93$ \\
\hline United States & - & - & 0.6 & $\ldots$ & $\ldots$ \\
\hline
\end{tabular}

Note: (...) denotes not available. In the case of the United States the only required value was that corresponding to the induced productivity coefficient. $\pi^{r}$ refers to the export elasticity of income required for convergence. It was computed implicitly using the equation of the basic model (i.e., equation [8]), and the minimum and maximum export-import elasticities of income of the different estimations provided.

Source: Pacheco López (2009); Senhadji (1998); Perraton (2003); Pérez Caldentey and MorenoBrid (1999); Moreno-Brid and Pérez Caldentey (2003). 
The exercise above is only one of different calibration exercises that can be undertaken using the above model. Other exercises can include higher levels of complexity and not necessarily place the weight of the adjustment on the export elasticity parameter.

Adjustment to ensure convergence can be brought about by changes also in the induced productivity of the follower country, or its import elasticity or a combination of the different parameters used in the model. The point of the exercise was to highlight the fact that under balance-ofpayments constraint conditions achieving convergence requires major and fundamental policy changes.

Further research steps in this direction, which fall outside the scope of this paper, but are a natural complement to it, is first to ascertain the conditions under which, if any, policy makers can effectively manipulate the above parameters for convergence in productivity. A second line of analysis worth pursuing is to inquire whether a change in the international financial architecture geared to remove the BPC constraint is a possible feasible alternative.

\section{BibLIOGRAPHY}

Abramovitz, M., "Rapid growth potential and its realisation: the experience of capitalist economies in the postwar period", in E. Malinvaud (ed.), Economic Growth and Resources: The Major Issues, London, Macmillan, 1979.

_- "Catching up, forging ahead, and falling behind", Journal of Economic History, vol. 46, no. 2, 1986.

—, "The elements of social capability", in D.H. Perkins and B.H. Koo (eds.), Social Capability and Long-Term Growth, Basingstoke, Macmillan Press, 1995.

Bairam, E.I., "Levels of economic development and appropriate specification of the Harrod foreign-trade multiplier", Journal of Post Keynesian Economics, vol. 19, no. 3, 1997.

Castellacci, F., "A 'technology-gap approach to cumulative growth': toward an integrated model. Empirical evidence for Spain, 1960-1997”, document presented at the Druid Academy Winter Conference, Copenhagen, 18-20 January, 2001. 
Chandra, R. and R.J. Sandilands, "Does modern endogenous growth theory adequately represent Allyn Young?", Cambridge Journal of Economics, vol. 29, no. 3, 2005.

Criscuolo, P. and R. Narula, "A novel approach to national technological accumulation and absorptive capacity: aggregating Cohen and Levinthal, Maastricht Economic Research Institute on Innovation and Technology, Research Memoranda no. 18, 2002.

Dahlman, C. and R. Nelson, "Social absorption capability, national innovation systems and economic development", in D.H. Perkins and B.H. Koo (eds.), Social Capability and Long-Term Growth, Basingstoke, Macmillan Press, 1995.

Davidson, P., International Money and the Real World, New York, St. Martin's Press, 1992.

- Financial Markets, Money and the Real World, Northampton, Edward Elgar, 2002.

Dixon, R.J. and A.P. Thirlwall, "A model of regional growth rate differences on Kaldorian lines”, Oxford Economic Papers, vol. 27, 1975.

Fagerberg, J. and B. Verspagen, "Technology-gaps, innovation-diffusion and transformation: an evolutionary interpretation", Centre for Technology, Innovation and Culture (TIK), TIK Working Paper no. 11/01, 2001.

Helpman, E., The Mystery of Economic Growth, Cambridge, The Belknap Press of Harvard University Press, 2004.

Kaldor, N., Causes of the Slow Rate of Economic Growth of the United Kingdom. An Inaugural Lecture, Cambridge, Cambridge University Press, 1966.

León-Ledesma, M.A., Accumulation, innovation and catching-up: an extended cumulative growth model, Cambridge Journal of Economics, vol. 26, no. 2, 2002.

McCombie, J.S.L. and A.P. Thirlwall, Economic Growth and the Balance-of-Payments Constraint, New York, St. Martin's Press, 1994.

_ , "Growth in an international context: a post Keynesian view", in J. Deprez and J.T. Harvey (eds.), Foundations of International Economics. Post Keynesian Perspectives, New York, Routledge, 1999.

McCombie, J.S.L.; M. Pugno and B. Soro, Productivity Growth and Economic Performance. Essays on Verdoorn's Law, New York, Palgrave Macmillan, 2002.

Moreno-Brid, J.C. and E. Pérez Caldentey, "Trade liberalization and economic growth in Central America", CEPAL Review, no. 81, LC/G.2216-P, 2003.

Nelson, R.R. and E.S. Phelps, "Investment in humans, technological diffusion and economic growth", American Economic Review, vol. 56, no. 2, 1966. 
Pacheco López, P., "Efectos de la liberación comercial en el crecimiento económico y la balanza de pagos en América Latina”, Investigación Económica, vol. LXVIII, no. 267, 2009, pp.13-49.

Pérez Caldentey, E., "Can balance-of-payments constrained economies pursue inflation targeting? A look at the case of Chile", Investigación Económica, vol. LXVIII, número especial 2009 Experiencias de objetivos de inflación, 2009a, pp. 103-146.

_ along Keynes's views", mimeo, 2009b.

Pérez Caldentey, E. and J.C. Moreno-Brid, "Terms of trade, exports and economic growth in Central America: a long-term view", Banca Nazionale del Lavoro Quarterly Review, no. 211(LII), 1999, pp. 431-449.

Perraton, J., "Balance of payments constrained growth and developing countries: an examination of Thirlwall's hypothesis", International Review of Applied Economics, vol. 17, no. 1, 2003, pp. 1-22.

Rogers, M., "Absorptive capability and economic growth: how do countries catchup?”, Cambridge Journal of Economics, vol. 28, no. 4, 2004.

Senhadji, A., "Time-Series estimation of structural import demand Equations: a cross-country analysis", IMF Staff Papers, vol. 45, no. 2, 1998, pp. 236-268.

Soro, B., "Fattori che regolano lo sviluppo della produttività del lavoro: fifty years on", in J. McCombie; M. Pugno and B. Soro (eds.), Productivity Growth and Economic Performance. Essays on Verdoorn's Law, New York, Palgrave Macmillan, 2002.

Targetti, F. and A. Foti, "Growth and productivity: a model of cumulative growth and catching-up", Cambridge Journal of Economics, vol. 21, no. 1, 1997.

Thirlwall, A.P., "The Balance-of-Payments Constraint as an Explanation of International Growth Rate Differences”, Banca Nazionale del Lavoro Quarterly Review, vol. 32, 1979.

Verdoorn, P.J. "Fattori che regolano lo sviluppo della produttività del lavoro", L'industria, vol. 1, 1949. (Translated by A.P. Thirlwall in D. Ironmonger, J. Perkins and T. Hoa (eds.), National Income and Economic Progress: Essays in Honour of Colin Clark, London, Macmillan, 1988.)

Verspagen, B. and B. Los, "The Evolution of Productivity Gaps and Specialization Patterns", unpublished, 2002.

Young, A., "Increasing returns and economic progress", Economic Journal, vol. 38, no. 152, 1928.

, "Nicholas Kaldor's notes on Allyn Young's LSE lectures 1927-29”, Journal of Economic Studies, vol. 17, no. 3/4, 1990. 